\title{
STILL WALKING THE TIGHTROPE
}

\author{
Lawrence D. Bobo \\ Department of Sociology and of African and African American Studies, \\ Harvard University \\ Michael C. Dawson \\ Department of Political Science, University of Chicago
}

This issue of the Du Bois Review: Social Science Research on Race is dedicated to the living memory and many contributions of distinguished historian John Hope Franklin. Writing in his autobiography Mirror to America, Franklin said that:

While I set out to advance my professional career on the basis of the highest standards of scholarship, I also used that scholarship to expose the hypocrisy underlying so much of American social and race relations. It never ceased being a risky feat of tightrope walking, but I always believed that if I could use my knowledge and training to improve society it was incumbent on me to make that attempt (2005, p. 376).

The spirit of these remarks and of his example to us all are the very raison d'etre for this journal. We are especially pleased to publish the reflections of five distinguished scholars on John Hope Franklin, the historian and the person. Clayborne Carson, Henry Louis Gates, Jr., Thomas C. Holt, Barbara Savage, and Julie Saville each bring a powerful, evocative lens to the enduring impact of Franklin on the history profession, the study of African Americans, and the problem of race.

It is fitting in this moment that we recall and re-energize the legacy of committed scholarship and real personal engagement in the struggle against racism epitomized by John Hope Franklin. We live in a context of Tea Party movements, anti-immigrant and anti-ethnic studies legislation in the State of Arizona, calls for recognition of a Confederate History month in the state of Virginia, and efforts to create a new, sanitized American history by those responsible for text book publishing in the State of Texas. Rhetoric of "taking back America," and assertions of the identity and claims of "real Americans," taking back from whom and as opposed to which "unreal Americans" inevitably raise pointed questions of on-going ethnoracial tensions and conflict. 
As the canard of post-racialism slowly atrophies in the face of persistent inequality and the most divisive politics seen in the United States since the Redemption era, this issue of the Du Bois Review probes the features of racial and ethnic division in the United States and around the world. We open with Henry Louis Gates, Jr. engaged in a provocative interview with eminent historian Nell Irvin Painter about her ambitious new book on Whiteness. We are particularly pleased to publish two articles challenging the de-racialized ideology of membership in the French Republic (Gueye and Keaton). We also include two review essays taking up the very nature of categorical inequality (Farley and Bobo), one examining the implications of the growth of the Black middle class (Jackson), one taking up the matter of racialized mass incarceration (Ossei-Owusu), and another taking on issues of modern Latino/a identity as it relates to immigration and settlement patterns (Vasquez).

Distinguished political scientist Hanes Walton, Jr. and colleagues offer a detailed assessment of how Black candidates and the issue of race have been treated in key assessments of presidential elections. A series of careful empirical articles then address compelling evidence of racial profiling in Detroit (Bates), of how segregation influences the employment prospects for Latinos (Dickerson von Lockette and Johnson), how Black racial socialization varies across generations (Nunnally), and the race-ing and gendering of achievement in elite institutions of higher learning (Massey and Probasco).

In these pages of tribute and of careful new scholarship we hope to carry forward the beacon of knowledge and courageous struggle held aloft with such poise, strength, and eloquence for so many years by the great John Hope Franklin.

\section{REFERENCE}

Franklin, John Hope (2005). Mirror to America: The Autobiography of Fobn Hope Franklin. New York: Farrar, Straus, and Giroux. 